\title{
Defamation Laws and Practice in the Age of Internet in Albania
}

\author{
Adrian Leka, Ph.D. \\ University of Shkoder "LuigjGurakuqi", Faculty of Law
}

\begin{abstract}
The picture of recent legal developments concerning defamation in Albania is mixed. On the one hand, several criminal defamation and insult statuteshave been abolishedsince 2012, following strong lobbying of human rights organizations. On the other, the application of criminal defamation laws has not stopped, while government officials and other high profile persons have discovered the power of civil defamation claims. Faced with intense criticism, the government has tried to re-introduce the abolished criminal defamation laws and has faced the same strong opposition and international outcry. In the meantime, defamation claims or threats thereof are routinely being used against the media or against the political opponent for the only purposes of creating tension and diffusing the attention of the public. The vagueness of the laws and the inconsistencies of judicial interpretation, helped in no little measure by judicial corruption and the political control of the judiciary, have widened the gap between constitutional and international guarantees of the freedom of speech and the actual enforcement of those guarantees. This article will briefly expose the history of defamation laws in Albania, the difficulties of their application, and the status of affairs concerning defamation laws and claims. ${ }^{1}$
\end{abstract}

Keywords: defamation, insult, media, journalist, criminal liability of journalists, Albania.

\section{Introduction}

In 2015, a drug related investigation suggested that the personal car of the Minister of Interiors of Albania had been used to transport drugs between Albania, Greece, and Italy. The Minister claimed that he had sold the car to people he did not know, but the ownership had not been transferred because all of this assets had been frozen to guarantee the payment of a defamation claim, brought against him by the former Prime Minister's children. These latter were a frequent target of accusations by the opposing party and quite often had resorted to defamation claims. It is an anecdotal example of various interesting facts about defamation laws and practice in Albania: people that could not be investigated for drug trafficking could be sued for defamation; defamation claims are quite common, but the plaintiff is not really interested to clean its image or gain the money that comes with the compensation. These claims are rather just another move in the political battlefield.

\section{Efforts to Reform Thedefamation Laws in Albania}

The Civil Code of the Republic of Albania (CC $)^{2}$ adopted after the fall of communism allowed persons that have suffered harm to their honor or personality to request the compensation of non-pecuniary damages ${ }^{3}$. It also allows compensation for the insultof the deceased or of the 'memory of the dead.'

\footnotetext{
1 Defamation in the Albanian context presents a terminology challenge. There are two concepts in the Albanian legislation: 'fyerje' and 'shpifje'. Since there is no standard usage for the English-language terms 'defamation', 'libel', 'slander', 'insult', etc., in official and unofficial translations that we could find, we have translated them respectively as 'insult' and 'defamation'. The terms are defined by the national legislation or the judicial case law thereof. See also, Defamation and Insult Laws in the OSCE Region: A Comparative Study, Commissioned by the OSCE Representative on Freedom of the Media DunjaMijatović, March 2017, https://www.osce.org/fom/303181?download=true (last visited 9/11/2018).

2 Adopted with Law no.7850, dated 7/29/1994.

${ }^{3}$ Article 625.

${ }^{4} \mathrm{~A}$ number of other countries in Europe maintain similar laws. See Supra at 1.
} 
The Criminal Code of the Republic of Albania $(\mathrm{CrC})^{1}$ adopted after the fall of communism included eight provisions that fall under the definition of criminal defamation laws ${ }^{2}$. These included simple insult and defamation, as well as insult and defamation against various categories of public officials and the humiliation of the flag and the national anthem ${ }^{3} \cdot \ln 2001$, four of these provisions were amended to further criminalize actions that were considered insulting or defamatory ${ }^{4}$. In 2008 , the crime of online insult for racist motives was introduced in the $\mathrm{CrC}^{5}$. All the eight offences were criminal misdemeanors ${ }^{6}$, which means that they were considered less serious and the defendants had more procedural benefits ${ }^{7}$. Procedurally, simple insult and defamationwere prosecutable by the private prosecutor (the accusing victim) ${ }^{8}$, in difference to other insult and defamation offences that used to be prosecutable ex officio by the prosecutor, but upon the criminal complaint of the injured party9.

The Albanian legislation did not include separate blasphemy and religious insult provisions.

The laws of civil and criminal defamation are widely criticized ${ }^{10}$. The issues stemming from these laws are inherent in their nature as they try regulate a highly subjective element, such as speech. On the other hand, the concept of reputation is also very subjective and often difficult to compensate as a loss.

In Albania, more than in other countries, this general criticism has only been part of the picture. The formulation of the laws themselves has been seen as a problem, but more concerning has been the application of those laws by the courts of the country. Civil and criminal defamation trials have seriously infringed the freedom of media and harmed the free public debate. As stated by Human Rights Watch in a report about the freedom of speech ${ }^{11}$, the observed violations are a combined result of flawed-and possibly unconstitutional-defamation laws, and the ways in which the Albanian courts apply such laws'. 12

\footnotetext{
${ }^{1}$ Adopted with Law no. 7895, dated 1/27/1995.

2 The criminalization of defamation continues the tradition of the previous communist regime. The Criminal Code of 1977 (Law no.5591, dated 6/15/1977) criminalized insult, defamation, and insult of public officials and persons conducting activities in the benefit of the society (Art. 185, 186, 120, and 206.)

3The list of defamation offences in the $\mathrm{CrC}$ of 1995 is as follows: simple insult (Art. 119), simple libel (Art. 120), insult of representatives of foreign countries (Art. 227), insult of public official because of their duty (Art. 239), insult of justice officials (Art. 318), simple libel (Art. 120), libel against public official because of their duty (Art. 240), libel against the President of the Republic (Art. 241), and public humiliation of the flag and national anthem (Art. 268/para. 2.)

${ }^{4}$ Law no.8733, dated 1/24/2001. Articles 119, 120, 239, and 240 were amended to add qualifiers for increased punishment. The sanctions provided for in Art. 239 were increased.

5 Law no.10023, dated 11/27/2008. Article $119 / \mathrm{b}$ of the CrC.

${ }^{6}$ As opposed to crimes.

${ }^{7}$ For example, a person is not generally arrested for a misdemeanor or, if sentenced to prison, they can have the sentence converted to a fine.

${ }^{8}$ The Criminal Procedure Code, Article 59. There is no investigation; the prosecutor participates in the trial, but has no role as the prosecution. The burden of proof beyond any reasonable doubt lies with the accusing victim.

9The Criminal Procedure Code, Article 284. The complaint is necessary for the start of the investigation. The injured party can withdraw it at any time and the prosecutor is obliged to dismiss the proceedings.

10Defamation Law in the Internet Age, Consultation Paper, November, 2017, The Law Commission of Ontario, Canada.

${ }^{11}$ The Cost of Speech: Violations of Media Freedom in Albania, Human Rights Watch, 6/13/2002, https://www.hrw.org/report/2002/06/13/cost-speech-violations-media-freedom-albania (last visited on 9/11/2018). 12 Id.
} 
It was generally viewed that the civil defamation laws did not constitute a sufficient regime ${ }^{1}$. Defamation was not defined ${ }^{2}$, a list of defenses against defamation claims was not provided ${ }^{3}$, no exceptions were made for particular forms of expressions, and no guideline was provided as to the manner of determining the amount of compensation 4 .

Criminal defamation statues were also not free from flaws. Initially, insult was not defined by the law, which allowed for definition to be made on a case by case basis. Even law textbooks included concerning definitions of what insult was ${ }^{5}$. Defamation was more defined, but it also included the concerning notions of 'honor' and 'dignity' that are not specific enough to be used as criteria for limiting the right to speech. More cause for concern was the existence of various criminal provisions that granted special protection from defamation to public officials, judges, the President of the Republic, etc. This was clearly in contradiction with ECHR established principle of less protection for public officials.

For all of these reasons, in 2004 various human rights organizations drafted and sponsored amendments to the civil and criminal defamation law 6 . The seven year saga of these proposed draftswould be a interesting example oflong-term efforts to find political support for a reform the politics does not want ${ }^{7}$.

The amendments were finally approved in $2012^{8}$. The most noteworthy change was the abrogation of all five statutes that criminalized defamation against public officials, including foreign ones, and the humiliation of foreign symbols.Furthermore, the imprisonment sentence was removed from all remaining provisions ${ }^{9}$, with the exception of insult of a judge that is still punishable with imprisonment.Also, changes made to the criminal defamation statutes clarified that the defendant should have acted with knowledge about the falsity of his statements. On the civil side, it was clarified that reputation is grounds for a civil compensation claim. A new Article added to the Civil Code established the criteria to be used in the determination of the amount of compensation. In general, the compensation should be proportional and able to remedy the damage caused, rather than punish the defendant ${ }^{10}$.Moreover the statute of limitations for these claims was greatly shortened.

It is also interesting to mention that the Albanian Constitution ${ }^{11}$, while providing for high state officials a broad immunity from criminal investigation and prosecution of any crime, limited the immunity from civil claims for defamation ${ }^{12}$. Therefore, persons with immunity could be sued for defamation, and in fact we will show below that defamation civil claims have been one of the tools employed in the political game. This element was spotted during the Constitutional amendments of 2012 and 2016 by various organizations, but was left out of the formal discussions. Therefore, parliamentarians in Albania do

\footnotetext{
${ }^{1}$ Article XIX Global Campaign for Free Expression, Memorandum per ligjinshqiptar per shpifjen, translated by OSCE Presence in Albania, London, 2004.

2ld.

${ }^{3}$ Such as the reasonable publication or the burden of proof on the plaintiff or protected statements, as established by the ECHR, for example, in The Sunday times v. The United Kingdom, ECHR (26 April 1979) or BladetTromso and Stensaas v. Norway, ECHR (20 May 1999) or Colombani and others v France, ECHR (25 June 2002). Some of these principles were also elaborated by Justice Brennan in New York Times v. Sullivan, 376 U.S. 254 (1964). In the same category of defenses, we would include the immunity that needs to be granted to internet service providers in their role as intermediaries, which was lacking in the Albanian law.

${ }^{4}$ This was a general feature of the Albanian civil law that did not provide for guidelines for determining the amount of civil compensation claims, leaving it up to each individual judge. Because of the way the court system is organized and the non-recognition of the precedent, the juridical case-law has not been able to establish unified criteria for the determination of damages.

${ }^{5}$ Courts have interpreted insult as something that includes 'humiliating, immoral or mocking words, images or actions, as well as satirical sketches', based on textbooks definitions. Such a broad interpretation is not in line with ECHR standards. See Supra at 15, that also quotes I. Elezi, Ligji Penal, Pjesë e Veçantë, Vëll.1, Tiranë: ShtëpiaBotueseLuarasi.

6 The amendments were drafted and sponsored by the Albanian Media Instituteand the Open Society Justice Initiative (SOROS) for more than seven years, with the assistance of many other organizations, including media and civil society, as well as the European Commission, whose support of the amendments was instrumental. For a more detailed discussion, seeMonitorimpërzbatimin e ligjevepërshpifjendhefyerjen, The Albanian Media Institute, Tirana 2015.

7 Darian Pavli, "Vrapimi i maratonës: përpjekjepërtëreformuarligjet e Shqipërisëpërshpifjen," prill 2013, http://institutemedia.org/Documents/PDF/D.Pavli\%20shqip\%20follow-up.pdf

${ }^{8}$ Adopted with law no.23/2012, for addenda and amendments to the Criminal Code, and with law no.17/2012,for addenda and amendments to the Civil Code.

${ }^{9}$ All of these misdemeanors are now punished with fines, albeit the fines were increased with the 2012 amendments.

10 Civil Code, Article 647/a.

${ }^{11}$ Adopted with Law no. 8417, dated 10/21/1998 and approved in a referendum.

12 Id., Article 73.
} 
not have immunity from defamation claims for their statements in the Assembly. Thisis a serious obstacle for the free public debate and for the functions of the Parliament.

\section{Defamation Laws in Other Countries and the Echr Case Law}

English defamation law has traditionally been the model for common law jurisdictions. The threshold for establishing defamation as a tort is not high. It is not necessary to find fault and the words are presumed false and that they caused harm, if the plaintiff is able to establish three elements: 1) that the words refer to him; 2) that they were published by a third party, and 3) that they tend to lower the plaintiff's reputation among average people ${ }^{1}$. The United States takes a different approach from all other common law countries. The practice of defamation law in the US has to take into account the strong constitutional protection of free speech, while internet service providers have immunity from defamation claims in their role as intermediaries².

Defamation is not a crime in common law jurisdictions, because it was abolished by the respective Parliament ${ }^{3}$ or because it was considered a nullity by the highest court in the country 4 .

The criminalization of defamation is common in Europe ${ }^{5}$, compared to common law jurisdictions. This reflects a more general tendency in the European Union to strike the balance between reputation and free expression closer to reputation and provides a useful counterpoint especially to the US heavy emphasis on freedom of expression 6 .

The practice of defamation law in Europe developed as a competition between two competing rights in the European Convention of Human Rights (ECHR): Article 8, privacy rights and Article 10, freedom of expression ${ }^{7}$. Article 8 ECHR does not explicitly mention a right to honor or reputation, but Article 10 does refer to reputation. It does not do so by making reputation a right, but it rather speaks of the protection of reputation or rights of others as the limitations to the freedom of expression, or, to make it simpler, some of the ways in which it can be interfered with this freedom. In the first defamation case brought under Article $10^{8}$, the European Court of Human Rights denied the Government's argument that the case concerned a conflict between Convention rights, holding that there is ... no need in this instance to read Article 10 in the light of Article 8'. However, the case law changed over the years with Article 8 and Article 10 cases $^{9}$, and reputation was recognized by the Court as a right that is granted protection under the ECHR ${ }^{10}$.

In the past decade, a consensus has been established between European and international human rights organizations regarding the risks that criminal defamation laws bring and the suggestion to abolish such laws and, in case, to abolish

\footnotetext{
${ }^{1}$ See for example, the Defamation Act, 2013 (UK), c 26 [UKDA 2013] or the Libel and Slander Act, RSO 1990, c L 12 [LSA].

2 Communications Decency Act, 47 US Code, art

230 [CDA (US)].

${ }^{3}$ Criminal libel in England and Wales was fully abolished by the Coroners and Justice Act 2009.

${ }^{4}$ In the United States, the landmark Supreme Court case was New York Times v. Sullivan, 376 U.S. 254 (1964). During the height of the civil rights movement, the New York Times ran a full page ad that suggested mistreatment of Rev. Martin Luther King, Jr. at the hands of Montgomery, Alabama Police. L.B. Sullivan, Montgomery's public safety commissioner, sued the New York Times for libel. After the Times was found liable in an Alabama court for $\$ 500,000$, the Supreme Court ruled unanimously against Sullivan, finding that the First Amendment provided a safeguard for freedom of speech. Justice William Brennan defined the importance of free speech in the United States: "Debate on public issues should be uninhibited, robust, and wide-open, and it may well include vehement, caustic, and sometimes unpleasantly sharp attacks on government and public officials. ...First Amendment protection does not turn upon the truth, popularity, or social utility of the ideas and beliefs which are offered." For a more detailed description of this and other US Supreme Court cases, see Criminal Libel in the Land of the First Amendment, Special Report for the International Press Institute, A. Jay Wagner and Anthony L. Fargo, October 2012 (revised and reissued September 2015).

5 Defamation is a crime in Austria, Germany, Italy, France, etc.

${ }^{6}$ Defamation Law in the Internet Age, Consultation Paper, November, 2017, The Law Commission of Ontario, Canada, https://www.lcocdo.org/en/our-current-projects/defamation-law-in-the-internet-age/ (last visited on 9/11/2018).

${ }_{7}$ Council of Europe, European Convention for the Protection of Human Rights and Fundamental Freedoms, 4 November 1950, ETS 5 [ECHR].

8Lingens v. Austria, ECHR (8 July 1986).

${ }^{9}$ Chauvy and others v. France, ECHR (29 June 2004) or Pfeifer v. Austria, ECHR (15 November 2007).

10 From Pfeifer: "a person's right to protection of his or her reputation is encompassed by Article 8 as being part of the right to respect for private life."
} 
prison sanctions for these crimes ${ }^{1}$. This shared opinion is based on the potential for abuse with criminal defamation law, when those are in the hands of the state to be applied, as well as on the greater effects that criminal sanctions bring to media and the freedom of speech, in general ${ }^{2}$.

The European Court of Human Rights has criticized the usage of criminal defamation laws, without explicitly requiring the abolition of all such laws. However, the Court has suggested that the imposition of imprisonment alone may be sufficient for the finding of a disproportionate remedy and, therefore, a violation of Article 10 (ECHR), regardless of whether the criminalization of defamation could be considered justified or not ${ }^{3}$.

On the other hand, the European Court, international organizations and watch dogs, all agree on the idea that public officials must be moretolerant of criticism than private persons, therefore any increased protection for public figures must be removed from the legislation. The European Court stated in Lingens v. Austria: 'The limits of acceptable criticism are wider as regards public or political figures than as regards a private individual. In a democratic society, the government's actions must be subject to the close scrutiny not only of the legislative authorities but also of the press and public opinion'. ${ }^{4}$

\section{The Application of Defamation Lawsin Albania}

The application of these laws has had chilling effects on the media. Defamation trials, both civil and criminal, against the media in the 1990s and 2000s, together with violence and threats against journalists and corruption in allocating state advertisements, undermined the development of a free, objective, and professional media in Albania ${ }^{5}$. These effects continue to plague the Albanian media to date ${ }^{6}$.

An analysis of six defamation criminal trials against journalists in Albania, made by Human Rights Watch ${ }^{7}$, exposed a number of violations of human rights.

One of these violations was the fact that defamation offenses against public officials were prosecutable ex officio, therefore the charges had to be proved by the prosecutor, while regular citizens had to prove the charges in a private prosecution setting ${ }^{8}$. Another very serious violation is the failure to properly apply the principle of burden of proof, which belongs to the accusing party. Very often, the journalists were convicted for failure to prove that their statements or (worse!) their opinions and judgements were true or in good faith 9 .

A review of some of these cases shows that the conviction of journalists is based on court decisions that are not sufficiently justified or substantiated. The courts pay little to no attention to international standards and to the interpretation made by the European Court regarding the balance between the right to private life and the freedom of expression, especially when

\footnotetext{
1 The UN Human Rights Committee has said that all states 'should consider the decriminalization of defamation and, in any case, the application of the criminal law should only be countenanced in the most serious of cases and imprisonment is never an appropriate penalty'. See, 'General comment No. 34', U.N. Human Rights Committee, 102nd session, published 12 September 2011, http://www2.ohchr.org/english/bodies/hrc/docs/GC34.pdf (last visited on 9/11/2018).

See also, the Tenth Anniversary Joint Declaration: Ten Key Challenges to Freedom Of Expression in the Next Decade (2010), http://www.oas.org/en/iachr/expression/showarticle.asp?artlD=784\&IID=1 (last visited on 9/11/2018).

${ }^{2}$ See Supra at 1.

3 In Cumpănă and Mazăre v. Romania, ECHR (17 December 2004), the Court noted that 'the imposition of a prison sentence for a press offence will be compatible with journalists' freedom of expression ... only in exceptional circumstances, notably where other fundamental rights have been seriously impaired as, for example, in the case of hate speech or incitement to violence.'

See also, Belpietro v. Italie, ECHR (2013), Mika c. Grèce, ECHR (2013), Mariapori v. Finland, ECHR (2013).

${ }^{4}$ See Supra at 36.

${ }^{5}$ See Supra at 15.

${ }^{6}$ See e.g., The Freedom House Report for Albania, 2018 in https://freedomhouse.org/report/freedom-world/2018/albania. "While the constitution guarantees freedom of expression, the intermingling of powerful business, political, and media interests inhibits the development of independent news outlets; most are seen as biased toward either the PS or the PD. Reporters have little job security and remain subject to lawsuits, intimidation, and occasional physical attacks by those facing media scrutiny".

${ }^{7}$ See Supra at 15.
}

${ }^{8}$ See Supra at 12, 13.

${ }^{9}$ See Supra at 15. 
public officials are concerned. One cannot help but think about judicial corruption and the political capture of the judiciary 1 . Even the High Court has not been willing to uphold the ECHR principles, but has instead dismissed without discussion many appeals filed by the defendants ${ }^{2}$, in spite of theserious rights violations committed by the lower courts.

The application of criminal defamation laws against politicians has followed a completely different route. A review of the cases handled by the High Court ${ }^{3}$ shows that politicians have usually brought claims against one another, but also using family members when those were part of the alleged defamation. In those cases where private citizens have been the accusing party, those individuals have been known as affiliated with one party or the other through ideology or business ties. The first wave of criminal defamation claims in the High Court started in 2009- 20104. In those times of great political tension, three criminal defamation claim were filed against the Prime Minister ${ }^{5}$ and one against a member of the Assembly ${ }^{6}$. All four cases concerned statements made in the Assembly ${ }^{7}$. The party in power responded with a criminal referral for defamation because of duty that eventually made it to the High Court ${ }^{8}$. The game of defamation claims either with the High Court directly or with the prosecution intensified in 2011 and carried on the following years. However, the High Court rejected all of this claims. Some of them were rejected on procedural grounds, but the High Court argued international and ECHR standards regarding defamation, and stressed the importance of protecting the freedom of expression while adjudicating these cases. The High Court also clearly placed the burden of proof with the plaintiff, in complete contradiction to what was happening with journalists at the same time.

The first defamation convictions in the High Court came in 2015 and, in those cases, the High Court moved completely from its previous position and placed the burden of proof on the defendant ${ }^{9}$. This wave of convictions did not last and the High Court went back to its additional interpretation, with the exception of rare convictions here and there that ironically concerned the same defendants ${ }^{10}$.

For a more recent picture, the Ministry of Justice reports that, during 2017, 126 criminal defamation cases were adjudicated in Albania ${ }^{11}$. These represent a 40\% increase over the number of the same categories of cases in $2016^{12}$. However, this considerable number of cases resulted in only eight convictions in $2017^{13}$, while the vast majority of cases was dismissed, most probably because of the withdrawal of the accusing victim. It is not possible to find reliable statistics of defamation civil claims, but it is fair to expect that those be on the rise too, because we are seeing a steep increase in civil claims for damages in general.

\footnotetext{
${ }^{1}$ For a discussion of the situation of the judiciary in Albania, see DokumentinAnalitik "Analizë e sistemittëdrejtësinëShqipëri" (Analysis of the justice system in Albania), drafted by the ad hoc Parliamentary Committee of Justice Reform, 2015.

http://www.euralius.eu/index.php/en/library/albanian-legislation/category/103-justice-reform-collection-of-laws

2See Supra at 15.

${ }^{3}$ Based on the Constitution, Article, the High Court had initial jurisdiction for criminal charges against the highest officials in the country, including those crimes that were prosecuted by the accusing victim. This changed with the Constitutional amendments made in 2016. ${ }^{4}$ It is interesting to note that the High Court has rendered its first initial jurisdiction decision only in 2009 and that the vast majority of these cases is for insult and defamation charges. It is almost ironic that in a country with endemic and pervasive corruption there have been more cases of defamation than corruption against high officials.

${ }^{5}$ These claims were filed respectively by the mother of the head of opposition and two businesspersons alleged to be affiliated with him personally.

6This claim was filed by another MP.

${ }^{7}$ Decisions no.9, dated 5/24/2010, no.6, dated 5/31/2010, no.7, dated 6/7/2010, and no.8, dated 6/21/2010.

8 Decision no.8, dated $7 / 1 / 2011$ against an MP.

${ }_{9}^{9}$ Decisions no. 8 and 9, dated 6/5/2015. The claims was filed by the Prime Minister against two MPs of the opposing party. The High Court stated that 'the evidence presented in the trial by the defendant...do not establish a basis to believe in the accuracy or truthfulness of his allegations'.

10 Decision no.13/1/1, dated 5/25/2017.

11 Insult takes the majority of these cases: 85 ; 40 are cases of defamation, and one is a case of insult of a judge.

${ }_{12}^{12}$ For judicial statistics, see the annual court statistics (VjetariStatistikor) published by the Ministry of Justice

www.drejtesia.gov.al/statistika.
}

${ }^{13}$ At least convictions in the first instance. It is not possible to know how many of these convictions were upheld in appeals. In Albania, the appellate court decision is the final one. 


\section{References}

[1] Internet development and social media in Albania Albanian Media Institute , 2015.

[2] Cybersecurity 2018 , laws and regulations, Albania 2018.

[3] Albania Business Law Handbook Volume 1 Strategic Information and Basic Laws.

[4] Law Enforcement and Investigation of Cybercrime in Albania, ISSN: 1857-7881,e-ISSN 1857- 7431.

[5] Legal and Institutional Reform in Albania After the Democratic Revolution,Prof. Dr. Aleks Luarasi.

[6] European regulation and Albanian media legislation: A comparative analysis of the main standards.

[7] Running the Marathon: The Effort to Reform Albania's Defamation Laws,Darian Pavli.

[8] Defamation in the Internet Age: Protecting Reputation Without Infringing Free Expression, September 11, 2012.

[9] Albania 2016 Human Rights Report,Country Reports on Human Rights Practices for 2016,United States Department of State.

[10] Defamation and Insult Laws in the OSCE Region: A Comparative Study.Scott Griffen, Director of Press Freedom Programmes, International Press Institute.

[11] The Law Of Defamation And The Internet By Matthew Collins.

[12] Comparative Study Of Best European Practices Of Online Content Regulation.Law and policy of online content regulation, in particular defamation online, in the light of Albanian legislative proposals.Kristina Irion Paolo Cavaliere, Darian Pavli.

[13] Defamation Law in Albania On the Way to Reform. Gent Ibrahimi March 9, 2005. 